\title{
Introduction to Nature of Minangkabau Culture With the Philosophy of Learning from the Nature Through Scientific Approach
}

\author{
Sofia Marni ${ }^{1 *}$ Delfi Eliza ${ }^{2}$ \\ ${ }^{*}$ FIP Universitas Negeri Padang, Padang, Sumatera Barat 25131, Indonesia \\ ${ }^{2}$ FIP Universitas Negeri Padang, Padang, Sumatera Barat 25131, Indonesia \\ *Corresponding author. Email: efi.sofiamarni@gmail.com
}

\begin{abstract}
Beside language as part of culture, children needs to know the culture and philosophy of the society. The Minangkabau people call their homeland the name of the nature of Minangkabau, with the philosophy, "learn from the nature" (Alam takambang jadi guru). The nature, is interpreted as a source of knowledge and even takes knowledge, skills and attitudes and normative behaviors that guides the people's lives. Making nature as a source of knowledge is in line with scientific approaches. The purpose of this study is to describe the introduction of the Minangkabau culture with the philosophical learn from the nature to become a professional teacher in early childhood learning through a scientific approach. The method used in this research was the R \& D method. The research sample were the kindergarten in Bukittinggi Municipality. The instrument in collecting data were learning programs including semester programs, RPPM and RPPH, which were integrated to the introduction of the culture of the Minangkabau with the philosophy. Observation was done during the teacher carrying out learning approach. The results showed that from the 3 selected themes, the results of the introduction of the Minangkabau natural culture with the philosophical learn from the nature so the teacher could be introduced by applying a scientific approach.
\end{abstract}

\section{Keywords: Philosophy of Minangkabau, learn from the nature, Scientific Approach, young learner}

\section{INTRODUCTION}

Besides learning language as part of culture, young learner needs to know the culture of the society. In West Sumatra with its Minangkabau culture, the children are provided with the introduction of the Minangkabau natural culture in early childhood learning is in line with the 2013 PAUD curriculum which aims to provide a broad learning experience for children to have the foundation to master the competencies needed for life in the present and the future, and develop their abilities as heirs to the nation's creative culture and care about the problems of society and the nation.

The natural culture of Minangkabau with the philosophical learn from the nature or Alam Takambang jadi Guru literally means "nature become the teacher" being a teacher in early childhood learning has not been integrated in 16 Kindergartens in the city of Bukittinggi that was observed in 2019. Survey results, documentation and interviews show that there is no kindergarten that introduces the philosophy of learn from the nature in early childhood learning. So it is deemed necessary to design a learning curriculum based on local Minangkabau culture with the philosophical learn from the nature in early childhood learning through a scientific approach.
Philosophical learn from the nature So the Teacher is generally interpreted as a wisdom of life to provide a holistic view of life based on reflections on life experience and scientific experience. Philosophy means doing contemplation to find solid foundations as a platform for everything that attracts human attention in pure proportions. (Sayuti, 2012: 182). A deep contemplation will give rise to a feeling of freedom, give birth to people who understand the basic themes of religiosity, outlook on life, and create humans who are able to build their own thoughts.

Humans who are able to develop their own thoughts, are human beings who are independent, religious, have a outlook on life and character. All the potential is not created by itself, but is obtained through education. Early childhood education / PAUD with a learning process that is carried out in a structured and planned manner, which is contained in a curriculum. The 2013 PAUD curriculum is designed with characteristics to optimize children's overall development which includes six aspects of development (religious and moral values, physical-motor, cognitive, language, social emotional, and art) which are reflected in the balance of attitudes, 
knowledge and skills, by using thematic learning and scientific approaches in providing educational stimulation.

Scientific comes from the word science which means knowledge. Seefeldt and Barbour (Dadan: 2018) mentioned that the ability of science in early childhood processes includes: the ability to observe, classify, draw conclusions, communicate, and apply them based on the scientific experience gained. Science invites children to think critically, with science children learn to find and prove the truth of something or reject something. It can be concluded that the scientific approach is a learning approach that gives children the opportunity to learn from real experiences, observe, try, find and infer what they see and observe.

The 2013 PAUD curriculum is philosophically aimed at developing children's abilities as heirs to a nation's culture that is creative and cares for the problems of society and the nation. Children as heirs of the nation's culture must know the local culture before knowing Indonesia as a whole. The Minangkabau natural culture with the philosophical learn from the nature is carried out through a scientific approach as a contextual experience for children to get to know Minangkabau culture early on.

Based on the description above, the problem that the researcher will adopt in this study is the Introduction to the Natural Philosophy of the Minangkabau learn from the nature in Early Childhood Learning with a Scientific Approach in Kindergarten Bukittinggi. This research was conducted in 16 kindergartens in the ABTB sub-district of Bukittinggi city with a population of 16 kindergarten heads and 87 group A and group B kindergarten teachers in $2019 / 2020$. This study aims to describe the development of early childhood learning curriculum based on Minangkabau natural culture with the philosophical learn from the nature through a scientific approach in kindergarten.

\section{REVIEW OF RELATED LITERATURE}

\subsection{The Philosophy "Learn from the Nature"}

The Minangkabau traditional philosophy adheres to inductive logic in understanding something, where everything is based on observations of what is happening in the environment. Then it was thought according to the truth standards adopted by the Minangkabau community, namely based on alua (plot), proper (propriety), and maybe, so that the natural philosophy of the nature emerged as a teacher (Yulika, 2012: 181). For the Minangkabau, the natural the nature being a teacher is proof of the existence of God that is certain and unshakable. God the Creator of all that exists. Therefore, the Minangkabau believe in the Koran as a guide and guide to their lives as popular adage. Adat Basandi Syarak, Syari Basandi Kitabullah Maintaining the Integrity of the Specifications.

The Minangkabau people see Nature with all its elements always consisting of four elements called nan ampek (the four). Just as there is sun, there is moon, there is earth, and there is star, there is day, there is night, there is morning and evening, there is east, there is west, there is north and there is south, there is fire, there is water, there is land, and there is wind, (Navis, 1984: 59). Each of these elements live with their existence in one harmony, which is dynamic with the dialectics of nature called Bakarano Bakajadian (having a cause and effect). Four according to the philosophical nature of Minangkabau namely the nature of the stem (plants), animal nature, the natural mind, and the supernatural, (Yulika, 2012: 182). The scientific approach is believed to be the golden bridge of the development and development of the attitudes, skills and knowledge of students, by promoting inductive reasoning. Inductive reasoning views specific phenomena or situations to then draw conclusions as a whole. Inductive reasoning puts specific evidence in a wider relation of ideas. (Suryana: 2017)

Inductive methods of nature emerge become teachers in early childhood learning in animal nature, which is observed in ant life. The ants go hand in hand and are organized so that it is revealed in the saying "seperti samuik bairiang" (like ants hand in hand). Ants are always shaking hands, if they meet, as the phrase "tagak sapo manyapo, sit tagua managua" (standing up greeting each other, sitting reprimanding each other). The other nature of the ants is the values in looking for food, "how can you get samo balabo, missing samo marugi" (if you can be as lucky, if you lose as losers). Ants can also be observed from how to settle and rest, and make defense in layers. All of the symptoms that ants for the Minangkabau people are natural are not teachers, which are interpreted inductively from natural phenomena (animals). Children are naturally attracted to animals from a young age (DeLoache et al., 2011 in Strous, Nyhout and Ganea: 2018) and animals are widely displayed in books or learning media designed for young children.

Natural inductive method of stems (herbs), observed in the life of a cassava. Cassava that still lives and grows everywhere and various conditions. Either planted, thrown into a pond, sanded, piled up with rubbish, in a ditch, and others cassava remains alive and thriving. The nature of cassava is often expressed "hiduiklah tuba cassava in the middle of the tacampak nyo tumbuah juo" (living like a cassava stem that lives anywhere) regardless of where it is located.

The method of the proof of the supernatural, namely in life that always has two dimensions "good and bad". Human life always faces these two realities that lead to the concepts of heaven and hell. Falsaat Minangkabau explains the good and bad meanings of life inductively through the analogy to the life of the trunk and animal realms above

The inductive method of thinking, when Minangkabau people think and understand every thought result. What is expressed in the proverbial Minang "pikia palito hati" (the mind of the lamp), means between raso jo pareso, meaning between mind and belief that must be in line. Raso is in the heart (soul, belief), and a sense of being under the realm of the mind (logic. Minangkabau people think and draw learning from the provisions of nature. So it is not uncommon for the proverbial and petitih that 
guide their customs sourced from events that occur in nature.

In fact children can be introduced to cultures that are appropriate to the context of the environment, to develop the ability to think and conceptualize social problems in accordance with their background, which aims to gain insight into life that occurs in the surrounding culture and also experience others, (Eliza: 2017). Early childhood education is a very important education for children in the next life. The quality of experience gained by children at an early age will make it more meaningful to achieve their future. (Eliza: 2013). The results of Joseph S. Agbenyegaa's research, Tamakloeb and Klibthongc, 2017) stated that children need to develop their views of the reality in their cultural community, they need to develop the ability to think, imagine and conceptualize social problems and gain insight about their personal lives and also the experiences of others.

The introduction of Minangkabau culture with the philosophical nature of takambang becomes a teacher through a scientific approach aimed at providing an understanding of children about the way the Minangkabau community views nature as a source of learning observed through the environment around the child with a scientific approach that is observed by the child continuously, (Eliza; 2017). All of them are summarized in two main points, namely culture and ideology. How to convey the teachings of noble advice through traditional expressions expressed using parable language and comparisons whose meanings are conveyed in terms of class (indirect).

Parables and comparisons can be made by referring to the nature and characteristics of plants (flora), animals (fauna), or to human behavior, (Hasanuddin; 2016). The closeness of the Minangkabau people to the natural environment of their lives and at the same time making the natural environment as a learning vehicle that can be understood as a formulation of local wisdom of the Minangkabau community that human life is very dependent on the natural environment and therefore humans must always maintain harmony with the natural environment.

\subsection{Scientific Approach}

The template is used to format your paper and style the text. All margins, column widths, line spaces, and text fonts are prescribed; please do not alter them. You may note peculiarities. For example, the head margin in this template measures proportionately more than is customary. This measurement and others are deliberate, using specifications that anticipate your paper as one part of the entire proceedings, and not as an independent document. Please do not revise any of the current designations.

Learning is carried out through a scientific approach in the play process. The scientific approach in the 2013 PAUD curriculum is a learning process that is designed so that students actively build attitudes, knowledge, and skills competencies through the stages of observing, asking questions, gathering information, reasoning, and communicating. The process of organizing learning is endeavored to be able to build ideas to express freedom, imagination and creativity so as to develop religious and moral values, motor skills, cognitive, language, social emotional and arts in accordance with the principles of child development. The scientific approach to questioning, is a dialogical approach between teacher and child on a predetermined theme, asking that children do can develop children's thinking skills. (Suryana; 2017).

Scientific learning in early childhood is very important for many aspects of child development. the researchers recommend that scientific learning be introduced before children enter school, even children from birth. (Eshach \& Fried, 2005; Watters, Diezmann, Grieshaber, \& Davis, 2000). This is important to help children understand the world, gather and process information as a key to children's learning to think scientifically (Eshach \& Fried, 2005; Ravanis \& Bagakis, 1998).

Children in their development and growth or early years experience several important things, so it is necessary to develop their views about the reality around and local culture, they need to develop the ability to think, imagine and conceptualize themselves in their environment and personal life. and the experiences of others around them, (Joseph S. Agbenyegaa, Tamakloeb and Klibthongc, 2017).

\section{RESEARCH METHOD}

This type of research used in this research is Research and Development ( $R$ \& D), because it is in accordance with the objectives to be achieved. Research and development is the research and development of education is the process used to develop and validate educational production, (Borg and Gall 1983).

Description of the study findings study the curriculum, learning programs in kindergarten, introduction of Miangkabau natural culture by integrating the philosophical nature of takambang to become a teacher into the learning program, including determining themes, making RPPM and RPPH. Next apply in the form of learning activities. Observing the effectiveness of learning activities, and at the same time discussing with the school principal again:

Preliminary research

- Literature study and field observations to gather theories and data relating to the philosophical nature of the Takambang become a Minangkabau teacher

- Study of needs analysis and teachers.

- The drafting of a Minangkabau culture-based scientific learning model based on the natural environment becomes a teacher. Continued by expert study and holding a Workshop"

- At this stage the researchers conducted a model trial, evaluation and revision

The researcher observes the implementation of the model trials, evaluates and revises model I

- Model Dissemination 
The broad trial phase, by choosing kindergartens with a large number of classes, is based on consideration of the number of teachers and kindergarten environments that are very adequate. This research develops the learning model so the success criteria can be seen through: Indicators or applicability criteria of the model can be seen from (1) indicators of teaching materials (2) benefits of teaching materials.

\section{RESULT AND DISCUSSION \\ 4.2. Implementing the philosophical}

Literature and field study results that researchers collected for the introduction of the old culture of Minangkabau with the philosophical nature of Takambang became a teacher through a scientific approach to several RPPM / RPPH learning programs with learning plans on learning themes such as themes 1) animals for stems, 2) plants for the trunk realm, 3) for the supernatural and the thought world integrated almost on all themes. Program by lifting learning material that is suitable with the learning objectives. Data is collected from the RPPM / RPPH of teachers in several kindergartens by integrating natural material into a teacher.

The design of Minangkabau natural culture learning with philosophical nature of Takambang becomes a teacher through a scientific approach.

The concept of the model to be designed refers to the development model design According to Dick and Carry, (1996), with the following components:

Formulate the Learning Objectives of Takambang in Being a Teacher

1). General purpose

The general purpose of learning Nature Takambang So a Teacher for early childhood is to know that nature created by God can provide good examples for life. Animals, plants and others are also God's creation Nature is also the same as humans. In the context of Minangkabau culture in accordance with the customs and culture of the Minangkabau, the custom is coded as basics of the Scriptures. It aims:

a) Fostering pride in children as part of the Minangkabau community.

b) Fostering gratitude in children to be able to respect themselves and others.

c) Introducing the Minangkabau cultural character to children.

d) Introducing local Minangkabau cultural values to children.

2). Special purpose

a) Instilling good habits in children to become:

(1) Knowing and understanding the cognitive realm of what is good and wrong.

(2) Being able to feel the affective realm of good value.

(3) Want to do the psychomotor realm of good things.

b) Applying the values of goodness in acting and behaving. c) Practicing good behavior continuously in daily life.

\subsection{Scientific Approach}

The introduction of the Minangkabau natural culture with the philosophical nature of Takambang became a teacher through a scientific approach. Designing learning, through a variety of materials and learning methods in introducing philosophical nature to the teacher.

Learning by integrating the natural culture of Minangkabau with the philosophical nature of Takambang becomes a teacher through a scientific approach to the material, methods and techniques of early childhood learning.

The learning plan is designed with special procedures carried out in learning activities. Learning plans are prepared starting from semester programs, weekly learning plans and daily learning plans and assessment of the learning process. The learning theme chosen is adapted to nature which will be explained to children. Selection of themes with appropriate learning materials and methods.

Table 1. Aspect observation sheet.

\begin{tabular}{|l|c|c|c|c|}
\hline Rated aspect & \multicolumn{3}{|l|}{$\begin{array}{l}\text { The philosophy of nature is not so } \\
\text { teacher }\end{array}$} \\
\cline { 2 - 5 } & $\begin{array}{l}\text { Natural } \\
\text { Trunk }\end{array}$ & $\begin{array}{l}\text { Animal } \\
\text { Realm }\end{array}$ & $\begin{array}{l}\text { Magical } \\
\text { Realm }\end{array}$ & $\begin{array}{l}\text { Nature } \\
\text { of } \\
\text { Mind }\end{array}$ \\
\hline $\begin{array}{l}\text { Children's } \\
\text { knowledge } \\
\text { about ATJG }\end{array}$ & $\sqrt{ }$ & $\sqrt{ }$ & $\sqrt{ }$ & $\sqrt{ }$ \\
\hline $\begin{array}{l}\text { Children's } \\
\text { understanding } \\
\text { of ATJG }\end{array}$ & $\sqrt{ }$ & $\sqrt{ }$ & $\sqrt{ }$ & \\
\hline $\begin{array}{l}\text { Application } \\
\text { of ATJG on a } \\
\text { daily basis }\end{array}$ & $\sqrt{ }$ & $\sqrt{ }$ & - & - \\
\hline
\end{tabular}

\section{CONCLUSION}

This research is about discussing the introduction of the natural culture of Minangkabau with the philosophical nature of Takambang being a teacher through a scientific approach. The results showed that a learning program was arranged by integrating the Minangkabau natural philosophical nature of Takambang into a teacher. the preparation of a learning program that teaches children about God's created nature can be a source of learning, can be used as a guide in acting and behaving. The preparation of this learning program experienced several obstacles, especially regarding the delivery of natural material from the Takambang to become a teacher who had been mistaken in the perception of the teacher in interpreting the philosophy, so that presenters were needed who really understood the natural culture of Minangkabau with the natural philosophy of Takambang being a teacher. 


\section{REFERENCES}

[1] Borg R. Walter, Gall P. Joyke and Meredith (Mark) D. Gall, 2014. Implementing Educational Research, How to Read, Conduct and Use Research to Solve Practical Problems. Pearson Education

[2] Eliza. 2013. Application of the Centrally Based Contextual Learning (CTL) Learning Model in Kindergarten. Pedagogigi UNP. Volume XIII No.

[3] Eliza, Delfi. 2017. Development of Character Learning Model Based on Traditional Minangkabau Stories for Early Childhood. PEDAGOGY: Journal of Early Childhood and Early Childhood Education Volume 3 Number 3b December 2017 P-ISSN: 25990438; E-ISSN: 2599-042X

[4] Eliza, Delfi. 2018. Wordless and Picture Books Model Development based on Minangkabau Folklore to Build Early Childhood Character and Literacy. Advances in Social Science, Education and Humanities Research, volume 178. 1st International Conference of Innovation in Education (ICoIE 2018)

[5] (Eshach \& Fried, 2005; Ravanis \& Bagakis, 1998).

[6] Hasanuddin. 2016. The Intangible Cultural Heritage of Minangkabau Traditional Expressions of the Local Wisdom of the Society in Advising and Noble Advicing. Human. Published by the Center for Humanities Studies. Volume XV No. October 2, 2016

[7] Navis A A. 1984. Nature Takambang Becomes a Teacher. Graffiti Press. Jakarta

[8] Nusyirwan. 2011. Minangkabau Man. National Library. Jogjakarta

[9] Sayuti M. 2005. Knowing Jo Nan Ampek. Mega Sari. Padang

[10] Suryana 2017. Mathematical learning models based on scientific approaches in preschool Conference Paper · October 2017

[11] Suryana, Dadan. 2018.

[12] S. Agbenyegaa, Tamakloeb and Klibthongc, (2017). Learning Classroom in South Korea ": An exploratory study. Asian Pacific Journal of research in Early Childhood Education. Vol. 11. No. 2 May 2017 pp 25-43.

[13] Storuse A Gabrielle, Nyhot Aglea and Ganea Patricia. 2018. The Role of Book Features in Yuong Children 's Tranffer of Information From Picture Books To Real - World Contexts. Frontiers in psychology. February 2018. Volume 9. Article 50

[14] Yulika, Febri. 2012. Minangkabau Epistemology The Meaning of Knowledge in Minangkabau Indigenous Philosophy. National Library. Jagjakarta [15] Travers, R, M, W, (Ed). (1973). Second Handook of Research on Teaching. Chicago: Randy Mc Nally 